\title{
Universiteit
}

Leiden

The Netherlands

\section{Cognitive behavior therapy and paroxetine in the treatment of hypochondriasis: A randomized controlled trial.}

Greeven, J.F.; Balkom, A.J.L.M. van; Visser, S.; Merkelbach, J.W.; Rood, Y.R. van; Dyck, R. van; ... ; Spinhoven, $\mathrm{P}$.

\section{Citation}

Greeven, J. F., Balkom, A. J. L. M. van, Visser, S., Merkelbach, J. W., Rood, Y. R. van, Dyck, R. van, ... Spinhoven, P. (2007). Cognitive behavior therapy and paroxetine in the treatment of hypochondriasis: A randomized controlled trial. American Journal Of Psychiatry, 164, 91-99. Retrieved from https://hdl.handle.net/1887/13160

Version: $\quad$ Not Applicable (or Unknown)

License:

Downloaded from: https://hdl.handle.net/1887/13160

Note: To cite this publication please use the final published version (if applicable). 
Link to online article

Cognitive behavior therapy and paroxetine in the treatment of hypochondriasis: A randomized controlled trial.

Greeven, J.F.; Balkom, A.J.L.M. van; Visser, S.; Merkelbach, J.W.; Rood, Y.R. van; Dyck, R. van; Does, A.J.W. van der; Zitman, F.G.; Spinhoven, P.

American Journal of Psychiatry, 2007, volume 164, pages 91-99

DOI: 10.1176/appi.ajp.164.1.91

http://ajp.psychiatryonline.org/cgi/reprint/164/1/91 